\title{
Reproductive Biology and Fishery-Related Characteristics of the Malabar Grouper (Epinephelus malabaricus) Caught in the Coastal Waters of Mafia Island, Tanzania
}

\author{
Lydia Gaspare ${ }^{1,2}$ and Ian Bryceson ${ }^{1}$ \\ ${ }^{1}$ Department of International Environment and Development Studies (Noragric), \\ Norwegian University of Life Sciences, 1432 Ås, Norway \\ ${ }^{2}$ Department of Aquatic Sciences and Fisheries, University of Dar es Salaam, P.O. Box 60091, Dar es Salaam, Tanzania
}

Correspondence should be addressed to Lydia Gaspare; lgaspare@yahoo.co.uk

Received 12 March 2013; Accepted 22 June 2013

Academic Editor: Ricardo Serrão Santos

Copyright (C) 2013 L. Gaspare and I. Bryceson. This is an open access article distributed under the Creative Commons Attribution License, which permits unrestricted use, distribution, and reproduction in any medium, provided the original work is properly cited.

\begin{abstract}
The reproductive biology and fishery-related characteristics of the Malabar grouper (Epinephelus malabaricus) (Bloch and Schneider, 1801) specimens were investigated. The size of females ranged from 25 to $113 \mathrm{~cm}$ total length $\left(L_{T}\right)$, with $50 \%$ sexually mature at $79 \mathrm{~cm} L_{T}$, and the males $\left(97 \mathrm{~cm}\right.$ to $\left.114 \mathrm{~cm} L_{T}\right)$ were larger than the females. Due to the sex ratios and size distribution of the sample, it appeared that the groupers change sex between 97 and $113 \mathrm{~cm} L_{T}$. However, the gonadal histology data lacked specimens in the transitional stage. The spawning peak occurred in November, as defined by the presence of ripe females, and the spawning season lasted from September to February. The size of the fish correlated positively with the water depth at capture, which is also related to oxygen levels in deep water being more favourable for larger fish. Larger specimens $\left(>100 \mathrm{~cm} L_{T}\right)$ were targeted by fishers between December and February, when the northeast monsoon coincides with calmer weather and the spawning season. Fishers were interviewed, and observations were made on fishing gear, vessels, and grounds. There was no indication that smallscale fishers targeted spawning aggregations; therefore, fisheries independent research is recommended in order to verify the time, location, and behaviour of the spawning of Malabar groupers for management and conservation purposes.
\end{abstract}

\section{Introduction}

The population size structure, mode of reproduction, maturity, and fisheries characteristics (fishing gear, vessels, and fishing grounds) of various Epinephelinae are well documented in the Western Atlantic, the Caribbean, Southeast Asia, and Australian waters [1-4]. In contrast, virtually no such data is available for the same species in Tanzanian waters, despite their frequent presence in local fish markets (pers. observations). Being highly priced fish, the Epinephelinae are heavily exploited in many tropical areas of the world for commercial purposes, aquaculture ventures (e.g., Epinephelus malabaricus and Epinephelus coioides) and for recreational and local consumption [4-6]. The increasing exploitation is attributed to growing markets, especially worldwide export markets for the fish $[7,8]$.
Groupers have long lifespans, are slow growing, relatively large in size, and have a low natural mortality rate. The larger species form breeding aggregations, and most species are protogynous hermaphrodites. Among the Epinephelinae, monandry protogynous hermaphroditism is the most common sexual pattern [9]. A few species, such as the Epinephelus coioides and the Epinephelus andersoni, are diandry, where the males can either develop from the females or they can develop directly from the juvenile phase [10-12]. The latter sexual pattern suggests that some females do not change sex at all, and some males do not pass through female stages at all.

We therefore argue that protogynous sex change, slow growth rates, late maturity, low numbers, growing to a large size, and the forming of breeding aggregations render the fish susceptible to overfishing [8,13-15]. Where the Epinephelus 
malabaricus have been studied, for example, in Prony Bay, New Caledonia [16], and in north-western Australia [17], they have been found to be protogynous hermaphrodites $[5,18]$ and form spawning aggregations [16]. The species is listed on the International Union for Conservation of Nature (IUCN) Red List as a near-threatened species [16]. Understanding the size structure, reproductive pattern, maturity, and spawning seasons of the Epinephelus malabaricus is important for proper fisheries management. For instance, the increase in fishing pressure targeting mature protogynous hermaphrodite fish is likely to selectively remove males from the population. This could result in imbalances in sex ratios (i.e., the population becomes female biased) which may reduce sperm availability. The subsequent reduction in sperm production could adversely affect spawning activities due to the diminished probability of egg fertilization $[3,9]$, and hence the resilience of the species. Likewise, a fishery that targets immature specimens that are smaller than sexually mature ones could compromise its sustainability, since this will reduce the number of specimens that enter the adult population and are able to breed. Garcia et al. [19] propose the adoption of balanced harvesting of fish of all size ranges, which would avoid the consequences to the ecosystem that come as a result of size-selective fishing.

Despite management efforts (such as gear management, temporary and permanent closed areas, and limitation of the number of fishers or vessels) that exist on the coast of East Africa [20], the near-shore fish resources on some parts of the East African coast have been exploited to various degrees by fishers using traditional fishing vessels and gear-like traps, hook-and-line, spearguns, and nets [21]. A similar situation has been reported in the Indo-Pacific and Caribbean regions, and some species of groupers have practically disappeared from commercial catches [22].

In 2002, the Fisheries Division of Tanzania endorsed a trial fisheries policy allowing the export of groupers of a minimum of $2 \mathrm{~kg}$ in weight [23]. The stated policy goal was to improve the livelihoods of coastal communities and increase fish product exports. However, no information on the reproductive pattern, size structure, and maturity of the groupers was available to ensure the sustainability of the fisheries. Understanding the population characteristics of the Epinephelus malabaricus is necessary in order to develop appropriate management and conservation measures. Therefore, this study aims to determine the reproductive biology and fishery-related characteristics of Epinephelus malabaricus caught by small-scale fishers in the inshore waters of Mafia Island, Tanzania. More specifically, the objectives of this study are to determine (1) sexual maturation based on the histology of the gonads, (2) the size structure and sex ratio, (3) the relationship between size and fishing gear used, and the depth at which fish were caught, (4) the size at first maturity, and (5) to document the spawning season. By analysing the reproductive pattern, size structure and maturity of Epinephelus malabaricus, we are generating information that is fundamental for predicting responses to fishing, conservation, and management initiatives in the waters of Mafia Island, Tanzania.

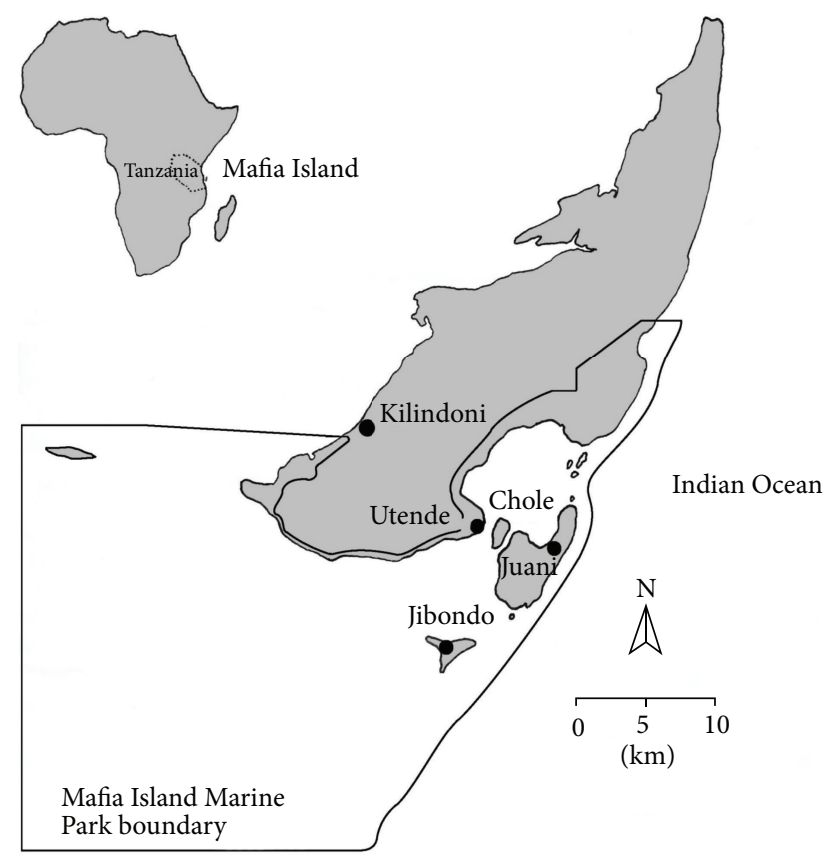

- Sampling locations

Figure 1: Map of Mafia Island, Tanzania, showing study area.

\section{Material and Methods}

2.1. Study Site and Sample Collection. Mafia Island and its small islets, located on its western and southern parts, lie approximately $120 \mathrm{~km}$ southeast of Dar es Salaam and $21 \mathrm{~km}$ offshore from the eastern extent of the Rufiji Delta. The island is approximately $48 \mathrm{~km}$ long and $17 \mathrm{~km}$ wide at its widest point and has an area of $413 \mathrm{~km}^{2}$. Several reefs and extensive intertidal flats are found along the southern and southwest part of the island. According to the latest census conducted in 2012 the population of Mafia Island is 46,438.

This study was conducted in the southern part of the island, which is part of a conservation area managed by the Mafia Island Marine Park (MIMP). The park is a multiple marine and land-use facility allowing human settlement within the park boundaries. In order to integrate conflicting interests between user groups, a zoning plan was adopted. The zones are divided into a core zone, where no form of environmental exploitation is allowed, a specified-use zone, where specific forms of environmental exploitation are allowed, and a regulated-use zone, where all legal forms of environmental exploitation are allowed (Figure 1).

The area under conservation covers $822 \mathrm{~km}^{2}$, of which $75 \%$ of the surface area is below the high water mark and more than $50 \%$ of the area is less than $20 \mathrm{~m}$ deep. The climate of the area is influenced by the biannual monsoon winds and the northward flowing East African Equatorial Current $[24,25]$. The area is characterised by dry and rainy seasons, and it is warm and humid throughout the year. The southeast monsoon (kusi) predominates from June to September with strong winds, while intermediate easterly winds (matilai) blow in October. The northeast monsoon (kaskazi) predominates from November to March with relatively gentle winds, 
and is followed by a rainy season (masika) from late March to the end of May. Scattered showers ( $m c h o o$ ) fall in August and September, while short rains (vuli) fall between October and December. The surface temperature of the sea ranges from $25^{\circ} \mathrm{C}$ to $31^{\circ} \mathrm{C}$, with June to August being a cool and dry season [26].

Specimens of Epinephelus malabaricus were purchased throughout the year from small-scale fishers operating at sea during the period between September 2009 and December 2010. The fishers resided in the villages of Jibondo, Juani, Utende, and Kilindoni. Information regarding the gear used to catch the fish, the fishing grounds, and the water depth were recorded at the time of sample collection. Furthermore, fishers were interviewed in order to solicit information regarding their knowledge of the spawning aggregation of the groupers.

2.2. Size Structure. The size structure of the Epinephelus malabaricus was assessed based on length and weight [27]. The total length $\left(L_{T}\right)$ of the specimens was taken using a measuring board and recorded to the nearest $1 \mathrm{~cm}$. The total wet weight $\left(W_{T}\right)$ was measured using a weighing scale and recorded to the nearest $1 \mathrm{~kg}$. The gonads were removed, blotted dry, and weighed $\left(M_{G}\right)$ to the nearest $0.01 \mathrm{~g}$ using an electronic weighing scale. They were examined macroscopically and then preserved in Bouin's solution for approximately 48 hours. They were then transferred into a solution of $70 \%$ ethanol and stored for histological examination in order to evaluate maturity.

2.3. Histological Analysis and Classification. The gonads were subsampled by taking tissue sections from three parts of the gonads: close to the junction of the two gonad lobes (proximal), from the middle (medial), and from the end of the gonad (distal). The tissue samples were dehydrated through a series of increasing concentrations of ethanol, cleared in xylene, infiltrated, and embedded in paraffin wax. Transverse sections of $7 \mu \mathrm{m}$, made using a hand rotary microtome, were mounted on glass slides using Mayer's egg albumin. The samples were then rehydrated, stained with Harris hematoxylin, and counter stained with eosin. Both ovaries and testes were examined using a light microscope. The ovaries were classified based on the presence of the most advanced and numerous types of oocytes present. The assignment to sexual categories and maturity development was based on criteria shown in Table 1.

2.4. Data Analysis. The length frequency distributions were used to describe the size structure of the fish, using the computer packages MS-Excel 2007 and OriginPro 7. Their maturity was identified by examining the gonads, and gonadal development was staged in order to identify seasonal maturational cycles. The size at sexual transition was estimated by examining the size range in which males overlapped with females. The median value and its confidence limits were taken to represent the size at which sex change occurs [34].

The timing of the spawning season was studied using the appearance of the gonads according to the predefined stages of maturation over time. Length-weight relationships were obtained using the log linear regression model $\log _{10} W_{T}=$ $\log _{10} a+b \log _{10} L_{T}$, where $W_{T}$ is the weight in grams, $L_{T}$ is the total length in centimeters, $\log a$ is the intercept of the regression model, and $b$ is the regression coefficient. The size at sexual maturity $\left(L_{50}\right)$ of females was estimated by fitting a logistic regression function, available from OriginPro 7, to the proportion of mature fish in $5 \mathrm{~cm} L_{T}$ size categories. The overall male to female sex ratio was calculated for the whole sample size at $5 \mathrm{~cm}$ class intervals. A two-sample independent $t$-test was used to determine the differences in size between females and males. For all statistical tests that were conducted, the level of significance was set to $P<0.05$.

\section{Results}

3.1. Histological Characteristics. The histological analysis of a total of 172 specimens of Epinephelus malabaricus showed no difference in maturation development between proximal, medial, and distal gonad sections. The gonads of Epinephelus malabaricus that were less than $92 \mathrm{~cm}$ in total length consisted only of ovarian tissues, and all juvenile specimens showed female gonads with previtellogenic oocytes. No male specimens were found in small sized classes. Moreover, no individual fish was found to be in a transitional stage, that is, possessing degenerative ovarian tissues, proliferating testicular tissues, or being mature resting females, spent females, or newly transformed males. The cellular development used to assign sexual maturity to different stages of both male and female fish is illustrated in Figures 2(a)-2(f) for females and Figures 3(a)-3(i) for males.

3.2. Size Structure and Sex Ratios. The statistical model for the length-weight relationship provided a good fit $\left(r^{2}=0.98\right.$, Figure 4). Epinephelus malabaricus had isometric growth, that is, $b=3.08$. Caught Epinephelus malabaricus specimens ranged from $25 \mathrm{~cm}$ to $114 \mathrm{~cm} L_{T}$ and from $0.26 \mathrm{~kg}$ to $27 \mathrm{~kg}$ in total weight. Females ranged from $25 \mathrm{~cm}$ to $113 \mathrm{~cm} L_{T}$ (mean $66.6 \mathrm{~cm} \pm 15.4 \mathrm{SD} ; N=136$ ) and from $0.3 \mathrm{~kg}$ to $23 \mathrm{~kg}$ in total weight (mean $5.3 \mathrm{~kg} \pm 3.7 \mathrm{SD}$ ). Males ranged from $97 \mathrm{~cm}$ to $114 \mathrm{~cm} L_{T}$ (mean $102.8 \mathrm{~cm} \pm 4.7 \mathrm{SD} ; N=36$ ) and from $12 \mathrm{~kg}$ to $27 \mathrm{~kg} M_{W}$ (mean $17 \mathrm{~kg} \pm 3 \mathrm{SD}$ ). Males were significantly larger than females (2-sample $t$-test, $\alpha=0.05$, $\mathrm{df}=163.596, P<0.0001)$. Up to $94 \mathrm{~cm} L_{T}$, there were only females, and beyond $94 \mathrm{~cm} L_{T}$ the sex ratio was one female for every four males (Figure 5). Overall, of the 172 specimens collected over a period of sixteen months, $55.3 \%$ were immature females, $23.8 \%$ were mature females, and $20.8 \%$ were males. Excluding the immature females, the adult sex ratio was $1: 1.3$ and $1: 3$ mature females to males during January and February, respectively. Mature female specimens were completely absent in the samples during March, April, and August. From May to July, and in November, the samples contained only mature females. In September and October, the ratio of mature females to mature males was $1.3: 1$ and $3.5: 1$, respectively, and the corresponding ratio in December was $1: 1.8$.

3.3. Relationships between Fish Size, Gear, and Depth of Capture. The majority (77.4\%) of the specimens of Epinephelus 
TABLE 1: Description of histological characteristics of various maturity stages of female (F) and male (M) gonads of Epinephelus malabaricus [1,28-32]. Terminologies for oocyte stages are based on Wallace and Selman [33].

\begin{tabular}{|c|c|c|}
\hline Stage & Development & Histological descriptions \\
\hline $\mathrm{F} 1$ & Immature & $\begin{array}{l}\text { Chromatin nucleolar stage dominant (large nucleus surrounded by a thin layer of cytoplasm; the } \\
\text { nucleus contains a single and large nucleolus). Lamellae highly organised and well packed with } \\
\text { previtellogenic oocytes, no signs of prior spawning in the form of brown bodies, postovulatory follicles } \\
\text { or atretic oocytes. Thin gonadal wall and no spermatogenic materials present. }\end{array}$ \\
\hline $\mathrm{F} 2$ & Late immature & Perinucleolar oocytes present \\
\hline F3 & Early ripening & $\begin{array}{l}\text { Chromatin nucleolar, perinucleolar, and cortical alveolar (appearance of York vesicles in the cytoplasm) } \\
\text { oocytes present, with migrating nucleus }\end{array}$ \\
\hline $\mathrm{F} 4$ & Late ripening & Cortical alveolar and yolk granule oocytes abundant \\
\hline F5 & Ripe & $\begin{array}{l}\text { Yolk plate formation is complete; oocytes are amoeboid in shape, and yolk granule oocytes (vitellogenic } \\
\text { stages) are dominant. }\end{array}$ \\
\hline F6 & Mature running ripe & $\begin{array}{l}\text { Oocytes in all stages of development may be present, although those in the early and late maturation } \\
\text { stages are dominant. Hydrated oocytes or postovulatory follicles are present indicating that spawning } \\
\text { had started. }\end{array}$ \\
\hline F7 & Mature resting & $\begin{array}{l}\text { Lamellae not compact and often vacuolated, filled with previtellogenic oocytes; presence of brown } \\
\text { bodies or atretic vitellogenic oocytes and intralamellae muscle bundles as the evidence of prior } \\
\text { spawning and thick gonadal wall. }\end{array}$ \\
\hline F8 & Spent & $\begin{array}{l}\text { Over } 50 \% \text { of the large yolk granule oocytes are atretic, brown bodies and postovulatory follicles are } \\
\text { generally present. Lamellae disrupted and disorganised, with empty spaces previously occupied by } \\
\text { oocytes. }\end{array}$ \\
\hline & Transitional & $\begin{array}{l}\text { Female tissue is degenerating; male tissue proliferating. Dorsal sperm sinus not fully formed; gonads } \\
\text { consist of ovarian tissues but sperm crypts are present. }\end{array}$ \\
\hline M1 & Maturing & $\begin{array}{l}\text { Post-transitional, newly transformed testes. Lobules containing spermatogenic cysts in all } \\
\text { developmental stages. No sperm within the sperm sinuses; seminiferous lobules may be evident with } \\
\text { previtellogenic oocytes in varying amounts that may fill the gonads. }\end{array}$ \\
\hline M2 & Mature ripening & $\begin{array}{l}\text { Lobules containing cysts of male sperm cells in all developmental stages (spermatocytes and } \\
\text { spermatids). Spermatozoa (tailed sperm) are free in the lumen. Little or no sperm in the sperm sinuses. }\end{array}$ \\
\hline M3 & Resting & $\begin{array}{l}\text { Little spermatogenic activity, some free residual of spermatozoa within lobule, lumen, and sperm } \\
\text { sinuses. Abundant cysts of spermatogonia inside the lobules. Vascularised and well developed stromal } \\
\text { tissues. }\end{array}$ \\
\hline M4 & Mature ripe & $\begin{array}{l}\text { Large pools of spermatids and spermatozoa in the large lumen of lobules and in the spermatic sinuses } \\
\text { (dorsal and central). }\end{array}$ \\
\hline M5 & Spent & Testes disorganised and vacularised, with numerous brown bodies and well developed stroma tissues. \\
\hline
\end{tabular}

malabaricus were captured by hook-and-line, $17.3 \%$ were captured by basket traps, and $5.3 \%$ were captured by seine nets. The length composition of the Epinephelus malabaricus varied markedly according to the method of capture (Figure 6). There is no world standard for measuring hook size. The measurements used here are based on the fishers' own descriptions of the hooks they use. The hooks were categorized by a number, with 1 being the largest hook and 12 being the smallest hook. Small hooks (numbers 6 to 12) and lines with a breaking strain (diameter) of $0.8 \mathrm{~mm}$ to $1 \mathrm{~mm}$, caught fish of $30 \mathrm{~cm}$ to $109 \mathrm{~cm} L_{T}$, while the larger hooks (numbers 1 to 5 ) and lines with a diameter of $1.3 \mathrm{~mm}$ to $1.9 \mathrm{~mm}$, caught specimens of $60 \mathrm{~cm}$ to $114 \mathrm{~cm} L_{T}$. Likewise, small basket traps (BT), measuring approximately $0.5 \times 0.4 \times$ $0.15 \mathrm{~m}$ with a mesh size of $3 \mathrm{~cm}$, caught small to medium sized fish of between $24 \mathrm{~cm}$ and $79 \mathrm{~cm} L_{T}$, while bigger basket traps, measuring approximately $1.06 \times 0.61 \times 0.30 \mathrm{~m}$ with a mesh size of $8 \mathrm{~cm}$, caught only larger fish of more than $100 \mathrm{~cm} L_{T}$. Seine nets with stretched mesh of $6.35 \mathrm{~cm}$ caught fish of less than $89 \mathrm{~cm} L_{T}$.
The size of the Epinephelus malabaricus that were caught correlated positively (Pearson correlation $=0.552, P<0.001$, $N=106)$ with the depth of capture. The majority $(68 \%)$ of Epinephelus malabaricus with sizes between $24 \mathrm{~cm}$ and $99 \mathrm{~cm} L_{T}$ were caught in shallow reefs of less than $20 \mathrm{~m}$ depth, while $32 \%$ of fish with sizes between $55 \mathrm{~cm}$ and $114 \mathrm{~cm} L_{T}$ were caught in deep reef areas at a depth range of $40 \mathrm{~m}$ to $400 \mathrm{~m}$ (Figure 7).

Field observations and interviews with fishers revealed that large Epinephelus malabaricus of more than $100 \mathrm{~cm} L_{T}$ were caught mainly using large hook-and-line, big basket traps, and wooden-planked boats (mashua) equipped with outboard engines. Fishers using passive gear (small and medium sized basket traps or hook-and-line) and traditional vessels (dugout and outrigger canoes) were able to catch smaller sized specimens of Epinephelus malabaricus found in shallow waters. The fishers stated that it is dangerous for them to use small vessels with large hook-and-line that catch large groupers because, once the fish is hooked, it can pull strongly and overturn the vessel. Also, strong water currents make it 

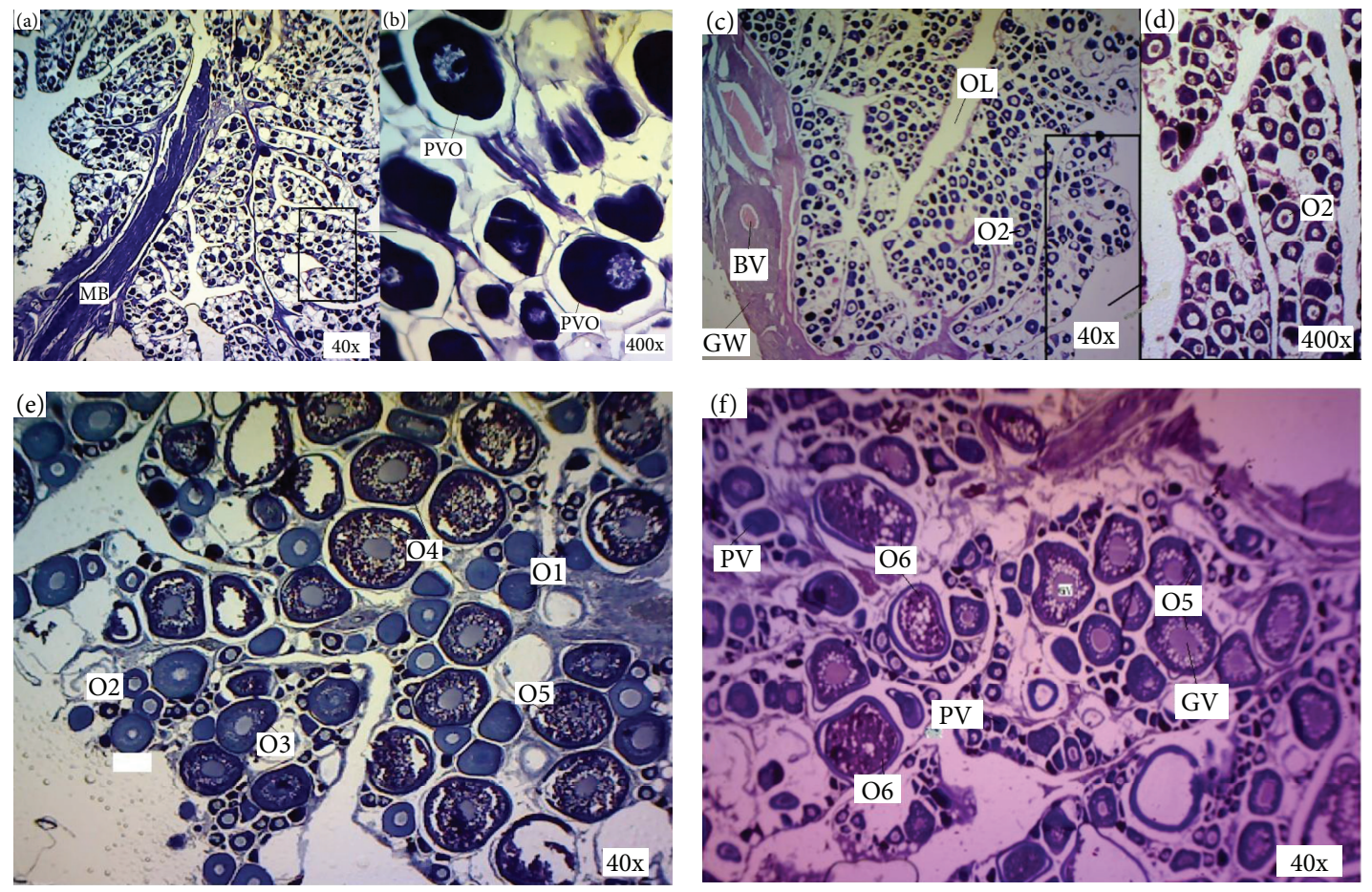

Figure 2: Histological section of ovarian stages of Epinephelus malabaricus (a) Immature (F1) collected 25 January $2010,66 \mathrm{~cm} L_{T}, 5 \mathrm{~kg} W_{T}$, $4.4 \mathrm{~g} G_{W}$ (c) Mature ripening (F3) collected 28 February 2010, $79 \mathrm{~cm} L_{T}, 9 \mathrm{~kg} W_{T}, 20 \mathrm{~g} G_{W}$; (e) Late ripening (F4) collected 30 January 2010 , $82 \mathrm{~cm} L_{T}, 9.5 \mathrm{~kg} W_{T}, 124 \mathrm{~g} \mathrm{G}_{W}$; (f) Ripe (F5) collected 19 October 2010, $96.5 \mathrm{~cm} L_{T}, 16 \mathrm{~kg} W_{T}, 185 \mathrm{~g} G_{W}$. PV: previtellogenic oocytes; OL: ovarian lumen; MB: muscle bundle, BV: blood vessel; GV: granule vesicle; GW: gonadal wall, O1-O6: oocytes stage F1-F6.

difficult to fish with a handline due to the line being pulled by the water. Furthermore, small vessels are unable to withstand strong winds, and hence handline fishing is minimal during the season when the seas are rough. The period from April to August is a rainy season, which is followed by strong southern monsoon winds that hinder access to deep reefs where the large Epinephelus malabaricus are found.

3.4. Sexual Maturation. The length at $50 \%$ sexual maturity $\left(L_{50}\right)$ of female Epinephelus malabaricus was $\sim 79 \mathrm{~cm}(7.5 \mathrm{~kg})$, based on the examination of 41 mature (F3-F6) and 102 immature (F1 and F2) female specimens (Figure 8). The minimum length at the onset of sexual maturity of the females that were analysed was estimated at $55 \mathrm{~cm} L_{T}$, and the size at $100 \%$ sexual maturity was $113 \mathrm{~cm} L_{T}$ (Figure 8). No significant differences in size were observed between F3, F4, F5, and F6, and mature ripening (M2) males were significantly larger than immature and ripening (F1-F4) females. Of the mature specimens collected from September to February, 31.7\% and $69.4 \%$ were female and males in a ripening condition, respectively (Table 2 ).

3.5. Spawning Season of Epinephelus malabaricus. Based on a histological assessment of gonads, ripe females were recorded in September $(N=2)$, October $(N=1)$, November $(N=3)$ and December $(N=3)$, and ripe males $(N=6)$ in September, October, December, and February. No sample of either sexes in ripe condition was collected between March and August (Figures 9(a) and 9(b)). Some fishers asserted that groupers do not aggregate to spawn; others said they did not know because they do not dive and therefore do not observe the fish underwater.

\section{Discussion}

4.1. Size Structure and Sex Ratios. We differentiated between females and males using histological analysis. The results show that the Epinephelus malabaricus from around Mafia Island displays isometric growth (i.e., $b=3.08$ ) similar to estimates reported by Kulbicki et al. [35]. Length frequency distribution analyses for Epinephelus malabaricus showed that male specimens were completely absent in the small size classes. The proportion of females declined as the size classes became larger, and very few females were present in the maximum size class. This is typical for haremic protogynous species where males attain a larger size in order to defend their territories or spawning sites that females visit $[36,37]$. Furthermore, the linear decrease in the proportion of females above the mean size at sexual maturity indicates that a sex change occurs as females become larger.

No differences in the size structure were noted when comparing the specimens used in this study with specimens of Epinephelus fuscoguttatus, also a monandric protogynous hermaphrodite species, collected from Australia's Great Barrier Reef [38]. In both Epinephelus malabaricus and Epinephelus fuscoguttatus, the mean size of males was significantly larger than that of females. However, some females were found in large size classes (in this study, one large female was found), indicating that perhaps not all females change sex [30]. This hypothesis could be tested in Tanzania by collecting 

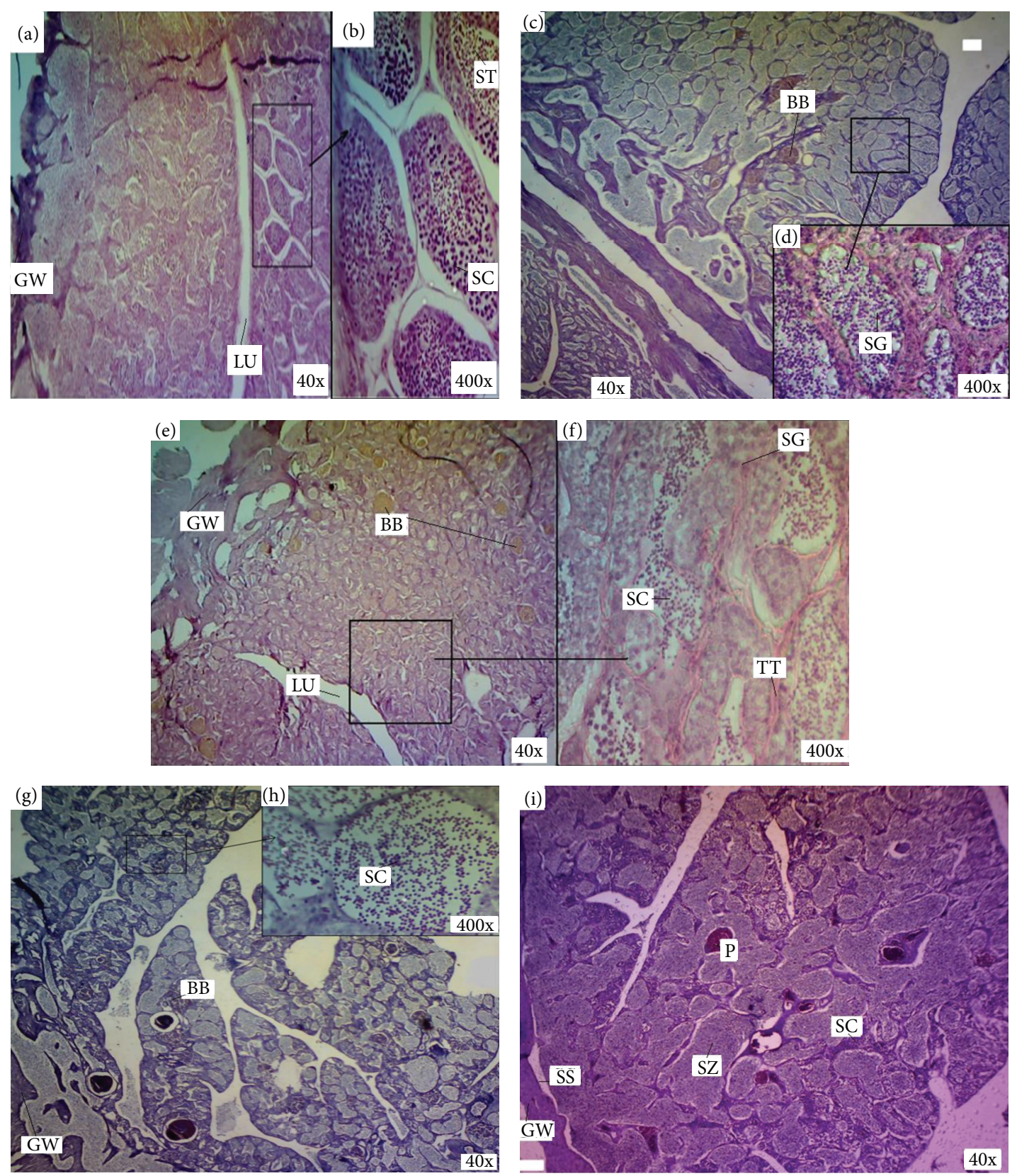

FIGURE 3: Histological sections of male Epinephelus malabaricus maturation stages of (a) mature ripening (M2) collected 1 February 2010, $97 \mathrm{~cm} L_{T}, 16 \mathrm{~kg} W_{T}, 20.66 \mathrm{~g} G_{W}$; (c) resting male (M3) collected 20 February 2010, $109 \mathrm{~cm} L_{T}, 23 \mathrm{~kg} W_{T}, 39.11 \mathrm{~g} G_{W}$; (e) resting male (M3) collected 28 February 2010, $100 \mathrm{~cm} \mathrm{~L}_{T}, 17 \mathrm{~kg} W_{T}, 39.53 \mathrm{~g} \mathrm{G}_{W}$; (g) mature ripening (M2) collected 23 January $2010,105 \mathrm{~cm} L_{T}, 18 \mathrm{~kg} W_{T}, 26.87 \mathrm{~g}$ $G_{W}$; (i) mature ripe (M4) collected 9 September 2010, $103 \mathrm{~cm} \mathrm{~L} L_{T}, 22 \mathrm{~kg} W_{T}, 68.86 \mathrm{~g} G_{W}$. BB: brown bodies, GW: gonadal wall, $G_{W}$ : gonad weight, $L_{T}$ : total length, LU: lumen, SC: spermatocytes, SG: spermatogonia, SS: sperm sinus, ST: spermatid, SZ: spermatozoa, TT: testicular tissues.

a bigger sample size of larger specimens of Epinephelus malabaricus from different populations throughout the year.

The monthly assessment of sex ratios indicated that males outnumbered females in December, January, and February. This may have been biased by the fishing activities coinciding with calmer sea conditions, meaning that large groupers in deep reefs were more accessible and therefore more easily targeted. Fishery-independent data would therefore be required in order to determine whether or not the ratios obtained from the specimen samples collected from the fishers represent those of the grouper population. However, there are problems associated with obtaining such data in the waters around Mafia Island. For example, local fisher knowledge may be essential in understanding the techniques used for catching groupers and the seasonal influence of monsoon winds, which hinder access to deep reefs during rough seas.

In our samples, few juvenile specimens of less than $25 \mathrm{~cm}$ $L_{T}$ were caught. Their absence in the samples collected is probably related to the selectivity of fishing gear that does not 
TABLE 2: Monthly frequency and average length $(\mathrm{cm})$ for Epinephelus malabaricus according to maturity stages. F1 and F2 are not included in female (F) : male (M) ratio. See Table 1 for descriptions of F1-F6 and M2-M5.

\begin{tabular}{|c|c|c|c|c|c|c|c|c|c|c|c|c|c|c|c|c|c|c|}
\hline & Jan & Feb & Mar & Apr & May & Jun & Jul & Aug & Sep & Oct & Nov & Dec & $N$ & Mean length $(\mathrm{cm})$ & SD & Min & Max & $\%$ of the total \\
\hline $\mathrm{F} 1$ & 6 & 5 & 10 & 2 & 4 & 9 & 2 & 3 & 7 & 13 & 15 & 6 & 82 & 57.8 & 11.2 & 25 & 79 & 47.7 \\
\hline $\mathrm{F} 2$ & 2 & 2 & 1 & 1 & 0 & 0 & 0 & 0 & 1 & 3 & 2 & 1 & 13 & 69.8 & 8 & 59 & 79 & 7.6 \\
\hline F3 & 2 & 0 & 0 & 0 & 2 & 1 & 0 & 0 & 1 & 2 & 2 & 0 & 10 & 76.8 & 4.7 & 73 & 88 & 5.8 \\
\hline $\mathrm{F} 4$ & 4 & 1 & 0 & 0 & 0 & 0 & 1 & 0 & 1 & 3 & 2 & 2 & 14 & 82.9 & 6.7 & 71 & 90 & 8.1 \\
\hline F5 & 1 & 1 & 0 & 0 & 0 & 0 & 0 & 0 & 0 & 1 & 1 & 4 & 8 & 87.4 & 7.1 & 76 & 97 & 4.7 \\
\hline F6 & 0 & 0 & 0 & 0 & 0 & 0 & 0 & 0 & 2 & 1 & 3 & 3 & 9 & 89.1 & 11.1 & 80 & 113 & 5.2 \\
\hline M2 & 7 & 5 & 0 & 0 & 0 & 0 & 0 & 0 & 1 & 0 & 0 & 12 & 25 & 101.2 & 3.4 & 97 & 108.5 & 14.5 \\
\hline M3 & 2 & 0 & 0 & 0 & 0 & 0 & 0 & 0 & 0 & 0 & 0 & 1 & 3 & 104.8 & 3.4 & 102.8 & 108.7 & 1.7 \\
\hline M4 & 0 & 1 & 0 & 0 & 0 & 0 & 0 & 0 & 2 & 2 & 0 & 1 & 6 & 106.5 & 6.9 & 101 & 114 & 2.9 \\
\hline M5 & 0 & 0 & 0 & 0 & 0 & 0 & 0 & 0 & 0 & 0 & 0 & 2 & 2 & 111.7 & 1 & 110.6 & 112.3 & 1.7 \\
\hline $\mathrm{F}: \mathrm{M}$ & $1: 1.3$ & $1: 3$ & - & - & $2: 0$ & $1: 0$ & $1: 0$ & - & $1.3: 1$ & $3.5: 1$ & $8: 0$ & $1: 1.8$ & $1.1: 1$ & & & & & \\
\hline
\end{tabular}

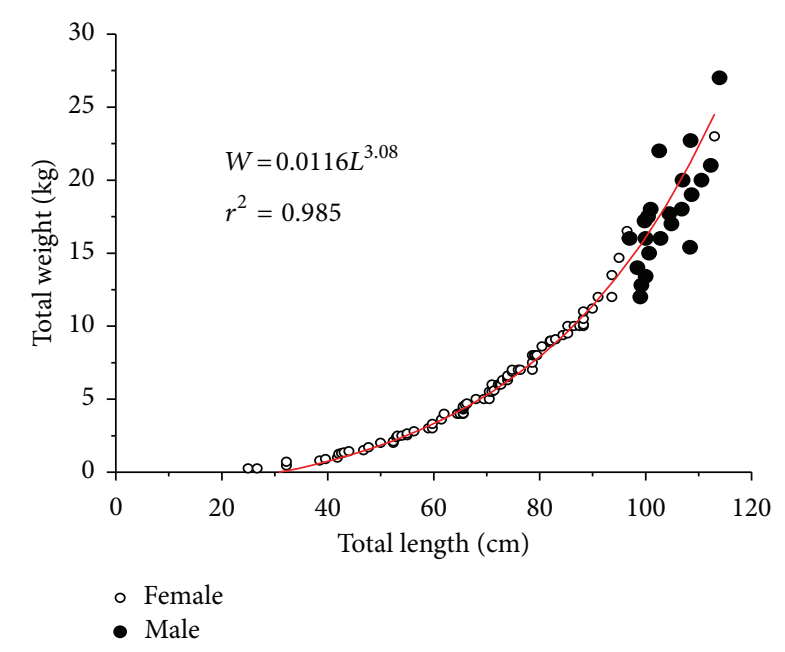

FIGURE 4: Length-weight relationship in Epinephelus malabaricus captured at Mafia Island between September 2009 and December $2010(N=172)$.

target juveniles, and perhaps also by their habitat preferences. It is possible that juvenile groupers occupy relatively rocky or coralline habitats [39] which are avoided by net fishers, or other structurally complex habitats like mangroves, in order to avoid predation.

Higher proportions of small and medium sized specimens were caught in shallow reefs, and large specimens were caught in deep reefs, which shows the depth stratification in size distribution [2, 40]. The bimodal size distribution according to depth may have several explanations. Perhaps it is related to gear selectivity, where small hooks and basket traps catching small fish are deployed in shallow waters, while only large hooks and basket traps catching large fish are deployed in deep water. Another reason for the size distribution could be related to oxygen levels in deep water being more favourable for large fish [41].

The maximum recorded total length for Epinephelus malabaricus is reported to be $150 \mathrm{~cm}$ [18], which corresponds to a weight of $53 \mathrm{~kg}$. None of the specimens collected in this study had reached such a large size. The particularly

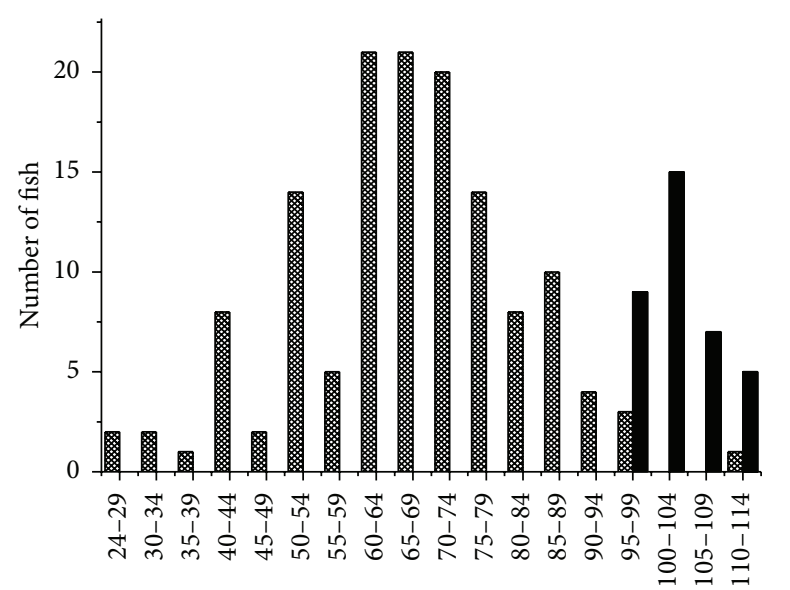

Total length $(\mathrm{cm})$

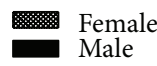

FIgURE 5: Size frequency distribution of female and male Epinephelus malabaricus $(N=172)$ collected from small scale fishers in Mafia Island between September 2009 and December 2010.

large specimens are possibly less vulnerable to fishing due to inaccessibility at depth, while small and medium sized specimens are more accessible in the shallow reefs. Other reasons for smaller specimens could be related to consumers' preference at local and international levels, which motivates fishers to target smaller sized fish. In the villages where the study was conducted, large groupers used to be associated with devils (locally known as chunusi). We were told by one old fisherman, who was 70 years old, that spiritualists do not eat groupers because they consider them to be "princes of devils." Some people resist eating groupers with black dots (typical of Epinephelus malabaricus) for fear of acquiring similar dots on their skin. However, with the current economic and social changes occurring in the area, these traditional taboos are eroding. Young generations of fishers seem to ignore these taboos and actively target large fish for greater monetary reward. Moreover, they are more involved in surrounding-net fishing, an active form of fishing 


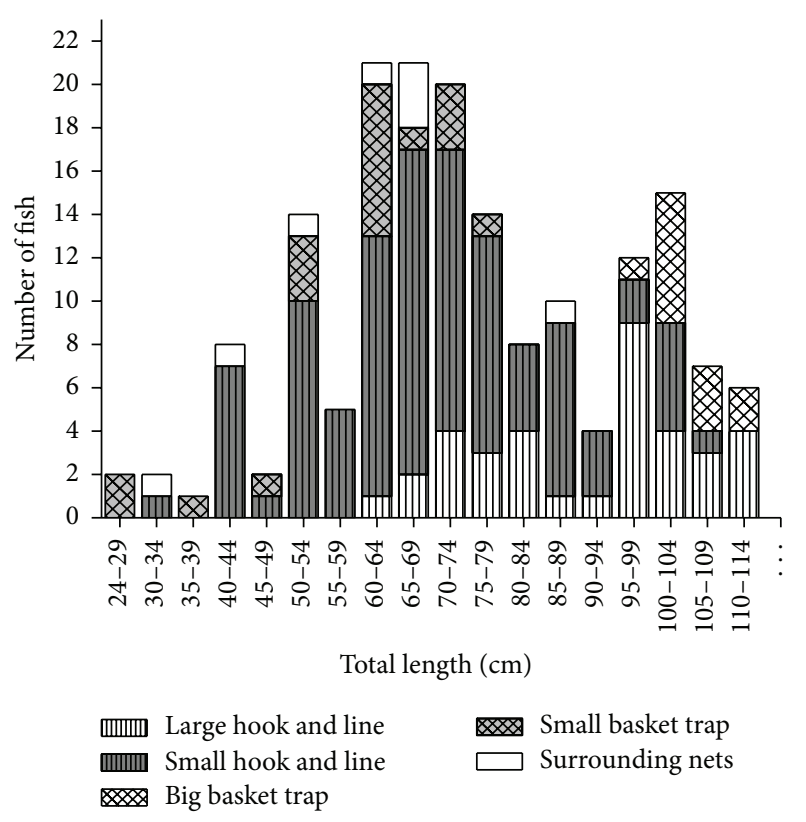

FIGURE 6: Length frequency distribution of the Malabar grouper Epinephelus malabaricus specimens caught by fishers using hookand-line, basket traps, and surrounding nets between September 2009 and December 2010 around Mafia Island.

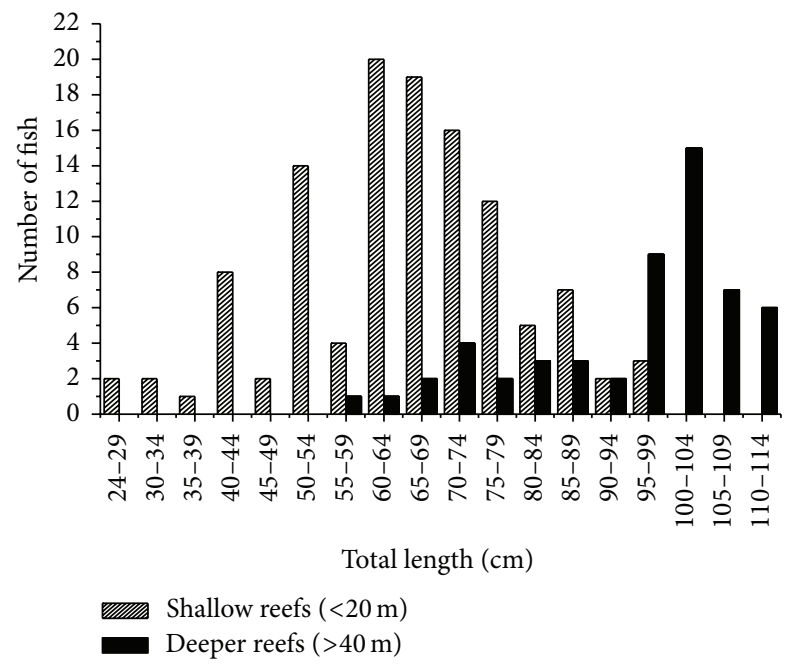

FIGURE 7: Number of Epinephelus malabaricus caught by small scale fishers at different reef depth profiles around Mafia Island between September 2009 and December 2010.

gear which is associated with a high yield in a relatively short period of time. They perceive handline fishing to be the work of old fishers, because it is time consuming, has a low yield, sometimes requires night fishing, and involves one or two people in an outrigger canoe.

On an international level, consumer preference is for smaller fish, because they do not like the taste of larger fish (C. Shekar, pers comm. February 2010). This motivates fishers to rather target small and medium sized fish and discourages them from targeting larger groupers. A group of fishers explained that they released large groupers $(\sim>50 \mathrm{~kg})$

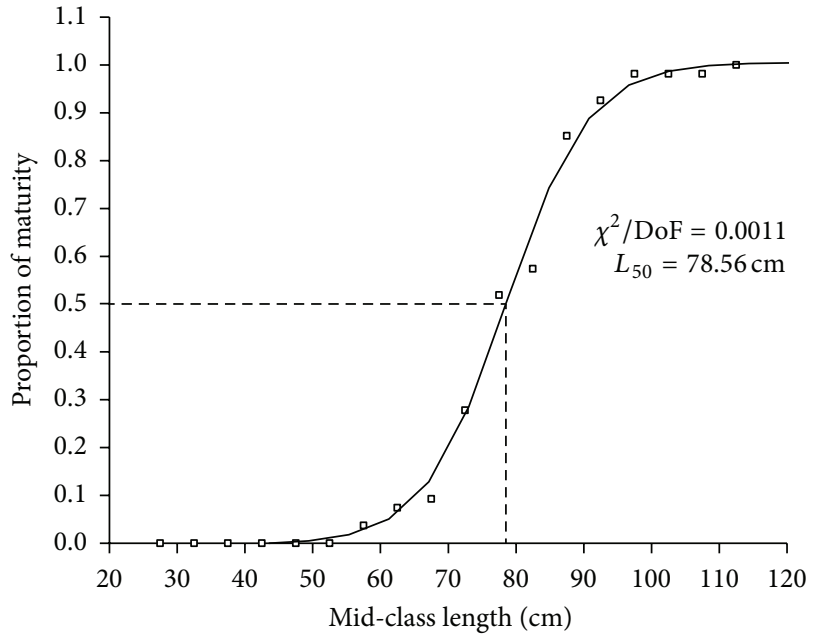

FIgURE 8: Proportions of sexually mature females (F3-F6) of Epinephelus malabaricus by $L_{T}$ fitted to a logistic function (dashed line indicates the mean $L_{T}$ at $50 \%$ sexual maturity $\left(L_{50}\right)(N=143)$.

that were caught in their basket traps because they are less marketable to the fish processing factories and the tourist hotels. Furthermore, larger fish take a longer time to sun-dry. These factors may render large Epinephelus malabaricus less prone to increased fishing pressure in the future.

4.2. Sexual Maturation. No evidence was obtained to confirm hermaphroditism based on the characteristics outlined by Sadovy and Shapiro [10], that is, either the presence of transitional specimens or the presence of atretic bodies in stages 1, 2, or 3 of oocytic atresia within testes. However, all the gonads of the immature specimens contained solely ovarian tissue, and a bimodal size distribution was apparent. The observed size distribution structure, with all small size specimens being female and the majority of large specimens being male, confirms that Epinephelus malabaricus is a monandric protogynous hermaphrodite species [11, 13, 42].

The size at 50\% maturity in Epinephelus malabaricus females was estimated at $78.6 \mathrm{~cm} L_{T}$. The results for $L_{50}$ were within the same range $\left(76.2 \mathrm{~cm}\right.$ to $\left.83.9 \mathrm{~cm} L_{T}\right)$ reported by Pember et al. [17] in north-western Australia. However, the $L_{50}$ estimation depends on the number and size of the sample, the sampling period, and the criteria used for diagnosis. While maturity was estimated to occur in a wide size range, our data indicated that sex change occurred in a narrower size range $(97 \mathrm{~cm}$ to $113 \mathrm{~cm}$ ), showing that females change sex at their maximum size. Pember et al. [17] report that Epinephelus malabaricus change sex in the range of $105.5 \mathrm{~cm}$ to $114.7 \mathrm{~cm}$ $L_{T}$, which concurs with the range estimated in this study.

No transitional specimens were found in this study; therefore, we assume the size range to be within the overlap between mature females and the first size recorded for males. Males started to occur slightly below the size of $100 \%(112.8 \mathrm{~cm})$ of female maturity, suggesting that they were secondary males, that is, all males are derived exclusively by sex change from adult females [43].

Neither spent nor resting females were found in this study. The reason for this may be the nature of the fishery, 


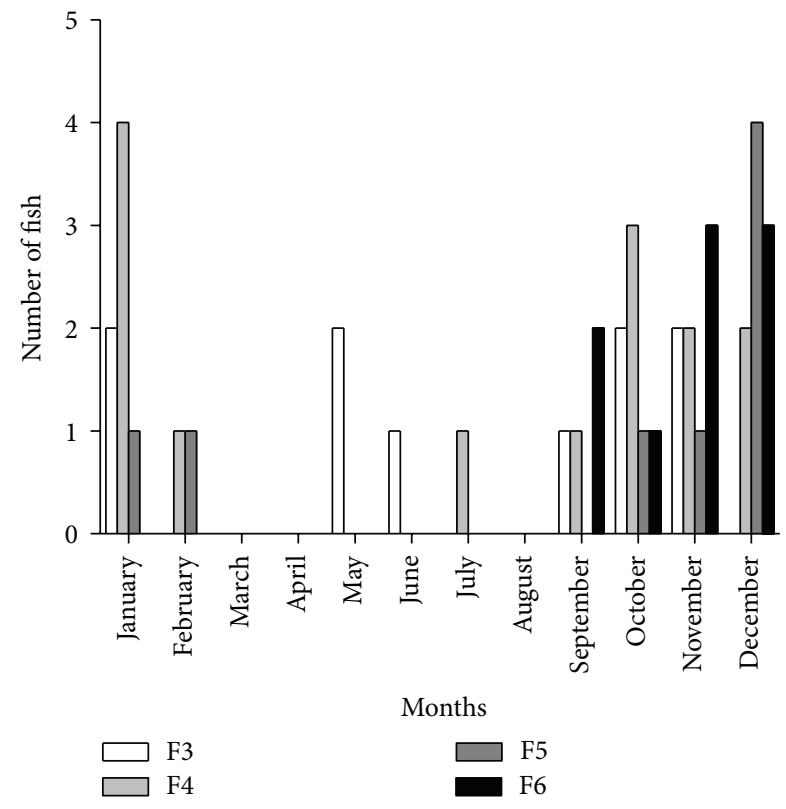

(a)

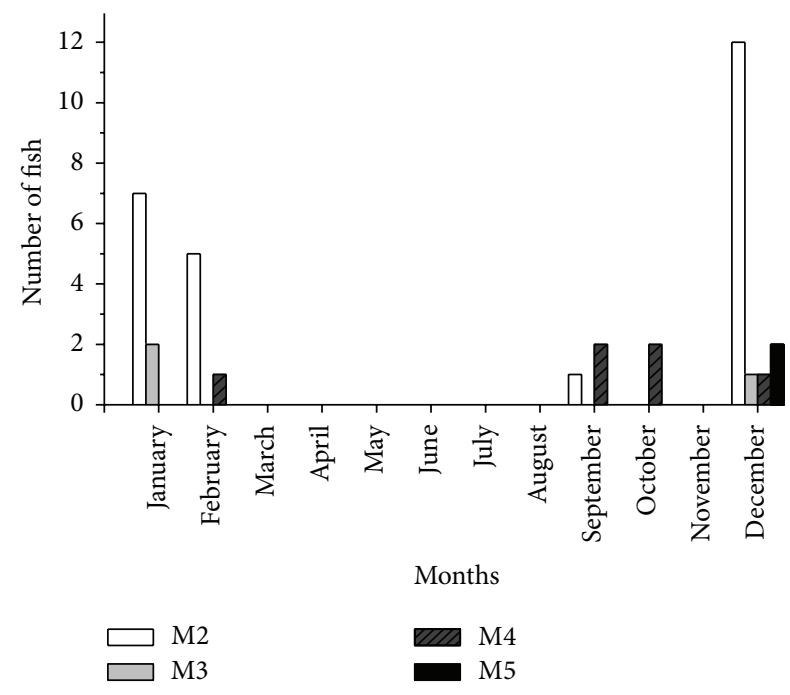

(b)

FIGURE 9: Monthly distributions of (a) female and (b) male Epinephelus malabaricus according to maturity stages.

whereby large sized specimens are restricted to deep reefs, which are not easily accessed by small-scale fishers. The accessibility of deep reefs is restricted to a few months (December to February) due to strong winds throughout the rest of the year. Therefore, the possibility of detecting sex change was affected by the lack of specimens caught from deep water during nonreproductive months. Shapiro [9] documents that sex change in some species of groupers is initiated during, or immediately after, spawning aggregations, but no observations or data are available as to whether Epinephelus malabaricus aggregate to spawn in the coastal waters of Tanzania.

4.3. Spawning Season of Epinephelus malabaricus. Based on gonadal histology, the prevalence of ovaries at stage F5 and
F6 (ripe and mature running ripe) in September to February indicates that Epinephelus malabaricus spawned during these months for a protracted period. According to Shapiro [9], large species of groupers tend to spawn for one to five months each year. A long spawning season, coupled with the presence of oocytes at various stages in a mature female, suggests that females spawn repeatedly during the breeding season $[29,44]$. The advantage of spawning occurring between September and February may be to enable hatched larvae to utilise the food made available by the increased abundance of plankton in Tanzanian waters at this time of year [26]. This concurs with the information obtained from elder fishers in the area, who believe that fish do not spawn, but come with the rains. One old fisher told us that "... Fish do not reproduce, they are brought by God and fall with the rains" (H. Ngwali, pers comm; interview no. 15, January 2010). It is possible that fishers have observed juvenile groupers in shallow waters during the rainy seasons (March to May).

Males showed no conclusive evidence of the spawning season since they did not exhibit large changes in gonadal weight. Furthermore, few male specimens were caught, with none being caught between March and August. This period is characterised by low surface water temperatures, when most fish come to shallow waters for feeding (pers. comm. with fishers). It may be that males of Epinephelus malabaricus do not come to shallow waters; due to their large size they stay offshore in deep reefs with more favourable oxygen levels [41].

The spawning season of Epinephelus malabaricus found in this study coincides with the calm conditions of the sea, which allows fishers to access deep reefs offshore. This period is associated with the grouper fishing season; however, it is not known whether fishers are targeting spawning aggregations. All interviewed fishers said that groupers do not aggregate in large numbers. Some species of grouper (Epinephelus polyphekadion, Epinephelus fuscoguttatus, and Plectropomus punctatus) have been reported to spawn in large numbers at specific locations and times in East Africa, which makes it easy for fishers to locate them [45]. Fishers' lack of awareness about spawning aggregations is possibly due to Epinephelus malabaricus migrating greater distances to spawn in deeper water [44], thus making them inaccessible to fishers. A further study would be required to verify the timing and location of the Epinephelus malabaricus spawning season.

\section{Conclusions}

Based on the biological findings in this study, the observed size distribution structure, whereby all small size individuals are female and the majority of large individuals are males, confirms that Epinephelus malabaricus is a monandric protogynous hermaphrodite species. The minimum landing weight of $2 \mathrm{~kg}$ proposed for the trial policy on groupers exports corresponds to immature Epinephelus malabaricus of less than $60 \mathrm{~cm} L_{T}$ which are not yet capable of reproducing; therefore, in order to ensure the survival and continued reproduction of the species, the stated minimum size limit needs to be reconsidered. The spawning season is from 
September to February, which coincides with the grouper fishing season, but this particular species is not known to have spawning aggregations. The Epinephelus malabaricus fished in Mafia Island waters include a range of immature specimens, ripe females and few large males; this seems to be a non-selective fishing pattern achieved by using gear of different types and sizes, which may contribute to ensuring the viability of Epinephelus malabaricus populations.

The deep reefs where large specimens of Epinephelus malabaricus are fished are found mainly outside the Mafia Island Marine Park area. Furthermore, there are no national fishing regulations stipulating the minimum or maximum size of grouper species that can be caught, the size of hooks and basket traps that may be used or the best time of year to catch groupers so as to avoid affecting their spawning activities. The natural seasonal closure of fishing due to strong southeast monsoon winds, coupled with the small size of fishing vessels and gear used by resident fishers, hinders access to deep reefs. These factors are currently acting as natural limitations to the fishing of large Epinephelus malabaricus. Another factor limiting the pressure on large fish is the consumer preference for smaller fish, at both local and international levels.

However, with the current and envisaged expansion and development interventions in the fishing industry, with the market focusing on the exportation of fish products, we anticipate that the number of fishers coming to Mafia Island to catch groupers may increase. The reason for increased numbers of fishers targeting groupers might be that groupers often weigh more than other demersal species; hence they yield more significant economic gains. Other reasons could be the improved access to fish markets (e.g., the presence of fish processing factories exporting fish products), the lack of alternative employment which leads to heavy dependence on fish resources, the exhaustion of fish resources in other parts of Tanzania, and the lower abundance of reef fish in the waters of the western side of Mafia Island. Therefore, fisheries management strategies need to reconsider the above aspects of the biology and ecology of Epinephelus malabaricus and adopt a precautionary approach, paying close attention to fishers' traditional knowledge and encouraging genuine involvement in decision making by the fishers who are dependent on the industry.

\section{Acknowledgments}

This study is part of the first author's PhD work and was funded by the Norwegian Programme for Development, Research and Education Project in Tanzania (NUFUTZ2007/10227/). The authors wish to thank numerous governmental organisations at village, district, and national levels for allowing them to conduct the research on Mafia Island. Specifically, they thank the MIMP administration for providing permission to conduct research inside the park and for providing space for our research equipment. They are grateful for the technical assistance on histological analysis by Mrs S. Nyalusi at the University of Dar es Salaam. Thanks also go to the fishing communities of Juani, Kiegeani, Jibondo, and Kilindoni for the valuable information and assistance provided to the authors during the fieldwork in Mafia Island. Finally, thanks go to Reidar Borgstrøm, Torbjørn Haugaasen, and Jeppe Kolding for making valuable comments both during the research and on the completed paper.

\section{References}

[1] M. A. J. Moe, "Biology of the red grouper Epinephelus morio (Valenciennes) from the eastern Gulf of Mexico," Professional Paper 10, Florida Department of Natural Resources. Marine Research Laboratories, St. Petersburg, Fla, USA, 1969.

[2] R. Thompson and J. L. Munro, "Aspects of the biology and ecology of Caribbean reef fishes: serranidae (hinds and groupers)," Journal of Fish Biology, vol. 12, no. 2, pp. 115-146, 1978.

[3] M. C. Mackie, "Reproductive biology of the halfmoon grouper, Epinephelus rivulatus, at Ningaloo Reef, Western Australia," Environmental Biology of Fishes, vol. 57, no. 4, pp. 363-376, 2000.

[4] Y. Sadovy de Mitcheson, M. T. Craig, A. A. Bertoncini et al., "Fishing groupers towards extinction: a global assessment of threats and extinction risks in a billion dollar fishery," Fish and Fisheries, vol. 14, no. 2, pp. 119-136, 2012.

[5] P. C. Heemstra and J. E. Randall, FAO Species Catalogue. Groupers of the World (Family Serranidae, Subfamily Epinephelinae). An Annotated and Illustrated Catalogue of the Grouper, Rock Cod, Hind, Coral Grouper and Lyretail Species Known to Date, vol. 16, No. 125, FAO Fisheries Synopsis, Rome, Italy, 1993.

[6] R. Yashiro, "Status of grouper breeding and culture in Thailand," http://library.enaca.org/Grouper/Research/Breeding/2000/ 0803.htm\#_ftnl, 1999.

[7] Y. J. Sadovy, T. J. Donaldson, T. R. Graham et al., The Live Reef Food Fish Trade While Stocks Last, Asian Development Bank, Manila, Philippines, 2003.

[8] Y. Sadovy and M. Domeier, "Are aggregation-fisheries sustainable? Reef fish fisheries as a case study," Coral Reefs, vol. 24, no. 2, pp. 254-262, 2005.

[9] D. Y. Shapiro, "Reproduction in groupers", in Tropical Snappers and Groupers: Biology and Fisheries Management, J. J. Polovina and S. Ralston, Eds., pp. 295-327, Westview Press, London, UK, 1987.

[10] Y. Sadovy and D. Y. Shapiro, "Criteria for the Diagnosis of Hermaphroditism in Fishes," in Copeia, pp. 136-156, 1987.

[11] S. T. Fennessy and Y. Sadovy, "Reproductive biology of a diandric protogynous hermaphrodite, the serranid Epinephelus andersoni," Marine and Freshwater Research, vol. 53, no. 2, pp. 147-158, 2002.

[12] E. M. Grandcourt, T. Z. Al Abdessalaam, F. Francis, A. T. Al Shamsi, and S. A. Hartmann, "Reproductive biology and implications for management of the orange-spotted grouper Epinephelus coioides in the southern Arabian Gulf,' Journal of Fish Biology, vol. 74, no. 4, pp. 820-841, 2009.

[13] S. Bannerot, W. W. Fox Jr., and J. E. Powers, "Reproductive strategies and the management of snappers and groupers in the Gulf of Mexico and Caribbean," in Tropical Snappers and Groupers: Biology and Fisheries Management, J. J. Polovina and S. Ralston, Eds., pp. 561-603, Westview Press, London, UK, 1987.

[14] G. R. Huntsman, J. Potts, R. W. Mays, and D. Vaughan, “Groupers (Serranidae, Epinephelinae): endangered apex predators of reef communities," in Life in the Slow Lane: Ecology and Conservation of Long-Lived Marine Animals. Symposium 23, 
J. A. Musick, Ed., pp. 217-231, American Fisheries Society, Washington, DC, USA, 1999.

[15] A. V. Morris, C. M. Roberts, and J. P. Hawkins, "The threatened status of groupers (Epinephelinae)," Biodiversity and Conservation, vol. 9, no. 7, pp. 919-942, 2000.

[16] A. Cornish and Grouper and Wrasse Specialist Group, "Epinephelus malabaricus," in IUCN, 2012. IUCN Red List of Threatened Species. Version 2012. 1, 2006, http://www.iucnredlist.org/ details/61338/0 .

[17] M. B. Pember, S. J. Newman, S. A. Hesp et al., "Biological parameters for managing the fisheries for Blue and King Threadfins, Estuary Rockcod, Malabar Grouper and Mangrove Jack in north-western Australia," http://www.cffr.murdoch.edu.au/ frdc/FRDC_2002-003.pdf, 2005.

[18] M. T. Craig, Y. J. Sadovy de Mitcheson, and P. C. Heemstra, Groupers of the World: A Field and Market Guide, NISC (Pty) Ltd., Grahamstown, South Africa, 2011.

[19] S. M. Garcia, J. Kolding, J. Rice et al., "Reconsidering the consequences of selective fisheries," Science, vol. 335, no. 6072, pp. 1045-1047, 2012.

[20] T. R. McClanahan, E. Verheij, and J. Maina, "Comparing the management effectiveness of a marine park and a multiple-use collaborative fisheries management area in East Africa," Aquatic Conservation, vol. 16, no. 2, pp. 147-165, 2006.

[21] B. Kaunda-Arara, G. A. Rose, M. S. Muchiri, and R. Kaka, "Long-term trends in coral reef fish yields and exploitation rates of commercial species from coastal Kenya," Western Indian Ocean Journal of Marine Science, vol. 2, no. 2, pp. 105-116, 2003.

[22] Y. J. Sadovy and A. C. J. Vincent, "Ecological issues and the trades in live reef fishes," in Coral Reef Fishes. Dynamics and Diversity in a Complex Ecosystem, P. F. Sale, Ed., pp. 391-420, Academic Press, San Diego, Calif, USA, 2002.

[23] I. Bryceson, N. Jiddawi, A. Kamukuru et al., "Fisheries study in Tanzanian coastal waters: the effects of trial export of finfish from Mafia Island on ecological-social resilience and vulnerability," Report, Ministry of Natural Resources and Tourism and Norwegian Embassy, Tanzania, 2006.

[24] T. R. McClanahan, "Seasonality in East Africa's coastal waters," Marine Ecology Progress Series, vol. 44, pp. 191-199, 1988.

[25] K. C. Garpe and M. C. Öhman, "Coral and fish distribution patterns in Mafia Island Marine Park, Tanzania: fish-habitat interactions," Hydrobiologia, vol. 498, pp. 191-211, 2003.

[26] I. Bryceson, "Seasonality of oceanographic conditions and phytoplankton in Dar es Salaam waters," University Science Journal, vol. 8, no. 1, pp. 66-76, 1982.

[27] "Length-based methods in fisheries research," in Proceeding of the ICLARM Conference, D. Pauly and G. R. Morgan, Eds., vol. 13, International Center for Living Aquatic Resources Management; Kuwait Institute for Scientific Research, Safat, Kuwait, 1987.

[28] C. L. Smith, "The patterns of sexuality and the classification of serranid fishes," American Museum Novitates 2207, 1965, http://hdl.handle.net/2246/5399.

[29] G. West, "Methods of assessing ovarian development in fishes: a review," Australian Journal of Marine \& Freshwater Research, vol. 41, no. 2, pp. 199-222, 1990.

[30] B. P. Ferreira, "Reproduction of the common coral trout Plectropomus leopardus (Serranidae: Epinephelinae) from the central and northern Great Barrier Reef, Australia," Bulletin of Marine Science, vol. 56, no. 2, pp. 653-669, 1995.
[31] M. A. Samoilys and A. Roelofs, "Defining the reproductive biology of a large serranid, Plectropomus leopardus," Technical Report 31, CRC Reef Research Centre Ltd., Townsville, Australia, 2000.

[32] K. Rhodes and Y. Sadovy, "Temporal and spatial trends in spawning aggregations of camouflage grouper, Epinephelus polyphekadion, in Pohnpei, Micronesia," Environmental Biology of Fishes, vol. 63, no. 1, pp. 27-39, 2002.

[33] R. A. Wallace and K. Selman, "Cellular and dynamic aspects of Oocyte growth in Teleosts," Integrative and Comparative Biology, vol. 21, no. 2, pp. 325-343, 1981.

[34] D. Y. Shapiro, "Sex reversal and sociodemographic processes in coral reef fishes," in Fish Reproduction: Strategies and Tactics, G. W. Potts and R. J. Wootton, Eds., pp. 113-118, Academic Press, London, UK, 1984.

[35] M. Kulbicki, N. Guillemot, and M. Amand, "A general approach to length-weight relationships for New Caledonian lagoon fishes," Cybium, vol. 29, no. 3, pp. 235-252, 2005.

[36] R. R. Warner, "Mating behavior and hermaphroditism in coral reef fishes," American Scientist, vol. 72, no. 2, pp. 128-136, 1984.

[37] R. R. Warner, D. R. Robertson, and E. G. Leigh Jr., "Sex change and sexual selection," Science, vol. 190, no. 4215, pp. 633-638, 1975.

[38] R. J. Pears, J. H. Choat, B. D. Mapstone, and G. A. Begg, "Demography of a large grouper, Epinephelus fuscoguttatus, from Australia's Great Barrier Reef: implications for fishery management," Marine Ecology Progress Series, vol. 307, pp. 259272, 2006.

[39] J. E. Randall, "A preliminary synopsis of the groupers (Perciformes: Serranidae: Epinephelinae) of the Indo-Pacific region," in Tropical Snappers and Groupers: Biology and Fisheries Management, J. J. Polovina and S. Ralston, Eds., pp. 89-188, Westview Press, London, UK, 1987.

[40] J. M. Leis, "Review of the early life history of tropical groupers (Serranidae) and snappers (Lutjanidae)," in Tropical Snappers and Groupers: Biology and Fisheries Management, J. J. Polovina and S. Ralston, Eds., pp. 189-237, Westview Press, London, UK, 1987.

[41] D. Pauly, Gasping Fish and Panting Squids: Oxygen, Temperature and the Growth of Water-Breathing Animals, International Ecology Institute, Oldendorf, Germany, 2010.

[42] M. Sheaves, "Large lutjanid and serranid fishes in tropical estuaries: are they adults or juveniles?" Marine Ecology Progress Series, vol. 129, no. 1-3, pp. 31-40, 1995.

[43] M. Liu and Y. Sadovy, "Early gonadal development and primary males in the protogynous epinepheline, Cephalopholis boenak," Journal of Fish Biology, vol. 65, no. 4, pp. 987-1002, 2004.

[44] Y. J. Sadovy, "Reproduction of reef fishery species," in Reef Fisheries-Fish and Fisheries Series 20, N. V. C. Polunin and C. M. Roberts, Eds., pp. 15-59, Chapman and Hall, London, UK, 1996.

[45] M. A. Samoilys, J. Church, B. Kaunda-Arara, A. Kamukuru, and N. Jiddawi, "Preliminary findings on spawning aggregations of reef fishes in East Africa," in Proceedings of the 10th International Coral Reef Symposium, pp. 1335-1346, 2006, http://www.reefbase.org/download/download.aspx?type $=10$ \&docid=12479. 

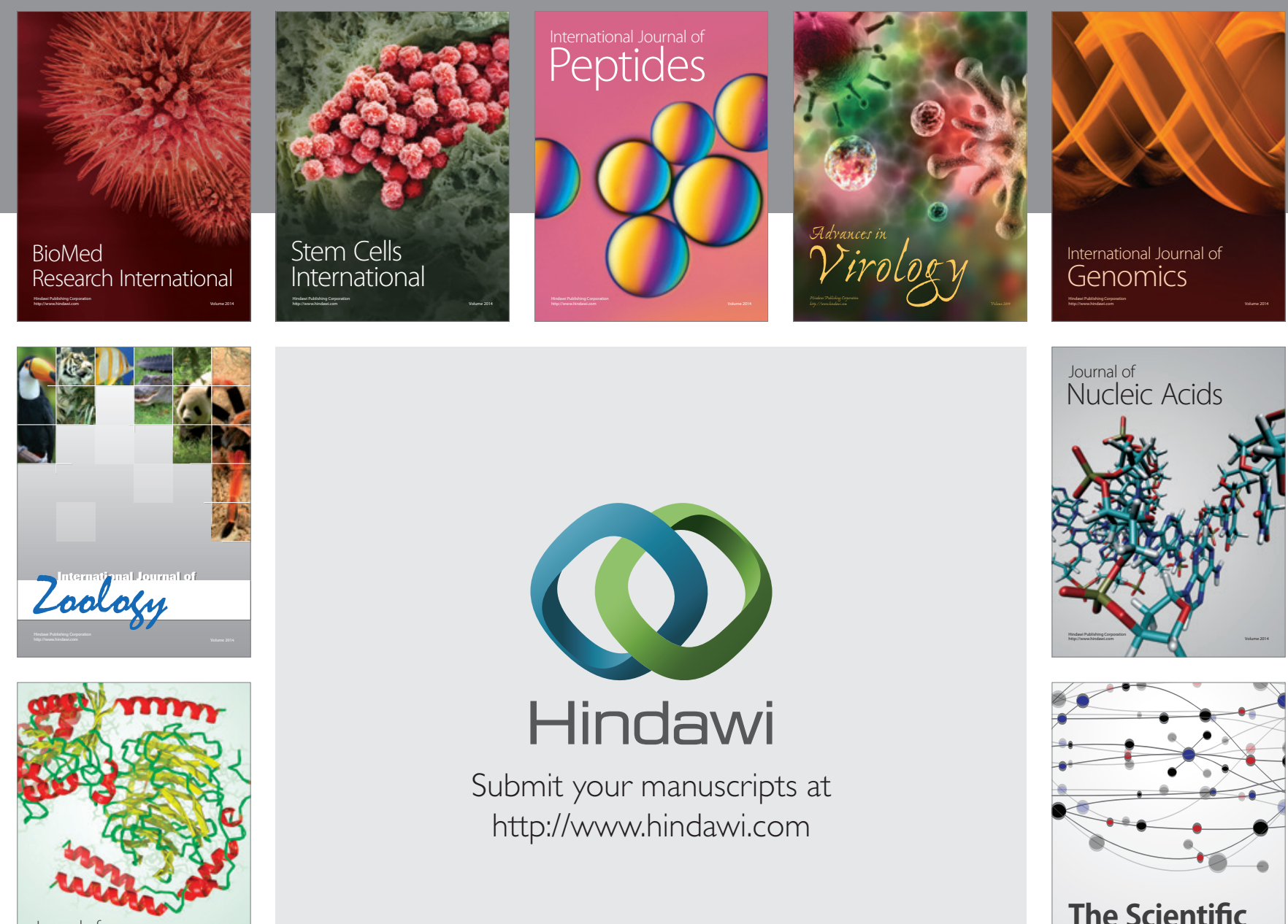

Submit your manuscripts at

http://www.hindawi.com

Journal of
Signal Transduction
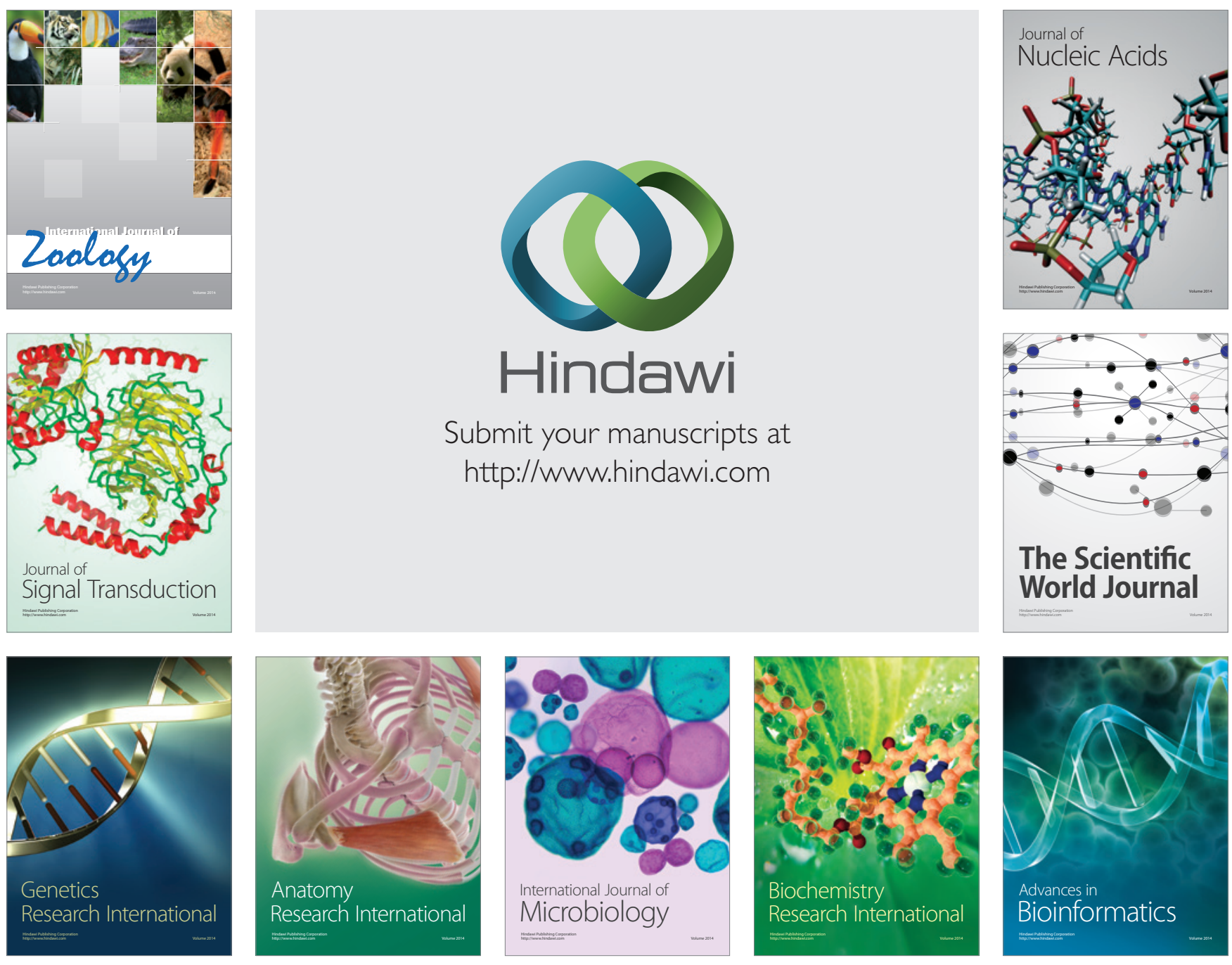

The Scientific World Journal
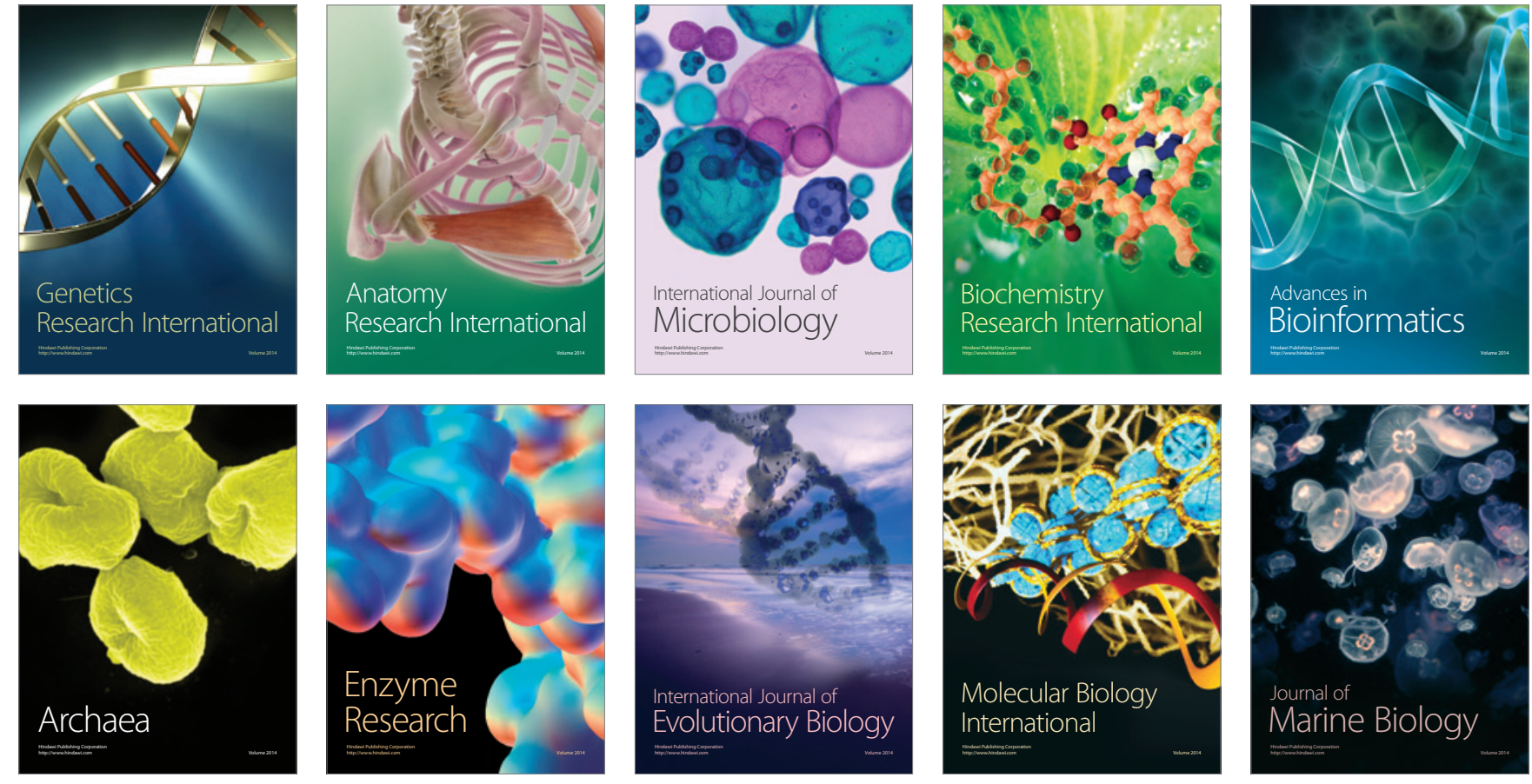